\title{
РОЛЬ МЕДИЧНОЇ СЕСТРИ У ПОДОЛАННІ ВІДЧУТТЯ САМОТНОСТІ В ПАЦІЄНТІВ ХОСПІСУ
}

\author{
Т. В. Томчук, А. О. Боб \\ Луцький базовий медичний коледж \\ ДВНЗ «Тернопільський державний медичний університет \\ імені І. Я. Горбачевського МОЗ Украӥни" \\ ННІ медсестринства
}

Відчуття самотності у пацієнтів хоспісу спостерігається у 96 \% хворих. Медична сестра, співпрацюючи із лікарями у хоспісах, допомагає пацієнтам долати складні наслідки самотності, шляхом надання консультацій, інформацій та підтримки. Медсестра повинна вміти розпізнати і вчасно звернути увагу на виражену самотність пацієнта. Кваліфікаційний, ефективний медсестринський догляд допомагає їм подолати відчуття самотності.

\section{THE NURSE'S ROLE IN THE LONELINESS OVERCOMING OF THE HOSPICE PATIENTS}

\author{
T. V. Tomchuk, A. O. Bob \\ Lutsk Basic Medical College \\ Educational-Scientific Institute of Nursing
}

The loneliness feeling of the hospice patients is observed in $96 \%$ of cases. In cooperation with the hospice doctors the nurse helps the patients to overcome the complicated results of loneliness by the way of giving consultations, information and support.The nurse should be able to recognize and pay attention to the patient's severe loneliness in time. The qualified effective nursing care helps them to overcome the loneliness feeling.

Вступ. Самотність - соціально-психологічний стан, що характеризується зменшенням або відсутністю соціальних контактів, поведінковою відчуженістю та емоційною скутістю індивіда [1]. Людина стає самотньою тоді, коли усвідомлює неповноцінність своїх відносин з людьми, відчуває гострий дефіцит задоволення потреби в спілкуванні. Самотність - тяжкий психічний стан, зазвичай супроводжується поганим настроєм і тяжкими емоційними переживаннями. Глибоко самотні люди, як правило, дуже нещасні, у них мало соціальних контактів, їхні особисті стосунки з іншими людьми обмежені або зовсім відсутні. Поняття самотності пов'язане з переживанням небажаних ситуацій, особисто неприйнятних для людини. Самотність звичайно переживається на двох рівнях:

1. Емоційний: почуття повної заглибленості в себе, приреченості, непотрібності, безладу, порожнечі, відчуття втрати, іноді жаху.

2. Поведінковий: падає рівень соціальних контактів, відбувається розрив міжособистісних зв'язків [2].

(C) Т. В. Томчук, А. О. Боб, 2016
Кожна людина індивідуальна, тому і переживання ії самотності також буде індивідуальним. Не важливо скільки років людині - в зрілому вона віці або старша - це почуття однакове для всіх. Звісно, інтенсивність та причина буде різною та значення самотності не змінюється.

Дослідження суб'єктивного відчуття самотності проводили у 2016 р. на базі Волинської обласної лікарні «Хоспіс». Всього було обстежено 20 пацієнтів. Відбір пацієнтів здійснювали за рівнем функціональних можливостей до спілкування. Для цього було використано методику діагностики рівня суб'єктивного відчуття самотності Д. Рассела, Л. Попелу, М. Фергюсона [3].

Основна частина. Методика Д. Рассела, Л. Попелу, М. Фергюсона дозволяє оцінити рівень суб'єктивного відчуття пацієнтом своєї самотності. Стан самотності може бути пов'язаний з тривожністю, соціальною ізоляцією, депресією, нудьгою. Необхідно розрізняти самотність як стан вимушеної ізоляції і як прагнення до самотності, потреба в ній.

Ми запропонували пацієнтам послідовно розглянути ряд тверджень, кожне оцінити з точки зору частоти 
їх прояву стосовно їхнього життя за допомогою чотирьох варіантів відповідей: «часто», «іноді», «рідко», «ніколи». Отримані результати визначили в балах від 20 до 60. Максимально можливий показник - 60 балів.
Результати діагностики показали, що 60 \% пацієнтів мають середній рівень суб'єктивного відчуття самотності, $35 \%$ - низький та $5 \%$ - високий рівень (рис. 1).

$60 \%$

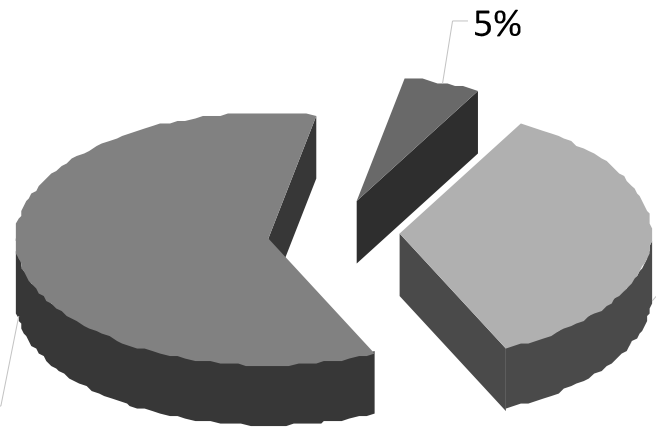

$35 \%$

низький рівень середній рівень високий рівень

Puc. 1. Розподіл рівня відчуття самотності у пацієнтів Волинської обласної лікарні «Хоспіс».

Таким чином, це свідчить про те, що стан самотності займає важливе місце в структурі особистості пацієнтів хоспісу. Для дванадцятьох пацієнтів самотність $\epsilon$ проблемою, яка має негативний вплив на ставлення до світу та до самого себе. Такі пацієнти переживають самотність за певних ситуацій.

7 пацієнтів мають почуття самотності високого рівня. Такі особи переживають самотність часто і гостро (табл. 1).

таблиця 1. Результати діагностики рівня суб'єктивного відчуття самотності за Д. Расселом, Л. Попелу, М. Фергюсоном

\begin{tabular}{|c|c|c|}
\hline Рівень & Кількість балів & Кількість пацієнтів \\
\hline Високий & $40-60$ & 1 \\
\hline Середній & $20-40$ & 12 \\
\hline Низький & $0-20$ & 7 \\
\hline
\end{tabular}

Діагноз пацієнта хоспісу, як правило, є причиною постійного емоційного напруження, страху та відчаю. Зусвідомленням тяжкості захворювання пацієнт вступає в якісно нову життєву ситуацію. Хвороба остаточно змінює всі перспективи людського життя, характер орієнтації на майбутнє. Така зміна - одна з найбільших причин зміни емоційного стану паліативних пацієнтів. Майбутнє стає невизначеним, не відповідає сформованим планам і очікуванням. В умовах захворювання відмова від професійної діяльності, порушення можливостей самообслуговування та задоволення потреб змінюють психологічний стан хворого. Першим сигналом перебудови $є$ виникнення якісно нового емоційного стану. Розпочинається процес об'єктивної зміни суспільної ролі. Спочатку пацієнт усвідомлює своє нове становище як невиліковно хворого, це ві- дображається безпосередньою емоційною реакцією на ситуацію. Пацієнт стає замкнений, відчужений, пасивний, відмовляється від спілкування.

Емоційні навантаження, які відчувають пацієнти хоспісу, визначаються насамперед їхніми особистісними особливостями, а також думками про біль і неминуче завершення життя. Крім того, інкурабельний хворий почуває себе слабким, безпомічним, шукає опіки. Усі пацієнти пов'язують своє відчуття самотності з переживаннями, що зумовлені хворобою та тяжким станом здоров'я. Твердження пацієнтів можна підтвердити даними медсестринського обстеження (рис. 2).

Проведене медсестринське обстеження підтверджує, що високий рівень суб'єктивного відчуття самотності може бути зумовлений порушенням задоволення фундаментальних фізіологічних потреб та обмеженими можливостями самодогляду та самообслуговування.

У цьому випадку важлива роль належить медичній сестрі - вона допоможе пацієнту адаптуватися до ситуації та відновити психологічну рівновагу, навчить пацієнта самодогляду, забезпечить задоволення основних життєво важливих потреб. У такий період медична сестра безпосередньо опікує хворого, втішає його, намагається полегшити його страждання, виконати його побажання. Ця материнська турбота $€$ сутністю професії медичної сестри, адже медсестринство - це мистецтво турботи про пацієнта [4].

Самотність для пацієнта хоспісу - це можливість зустрітися з самим собою, яка багато чого дає особистості: пізнання себе, інших, можливість по- 

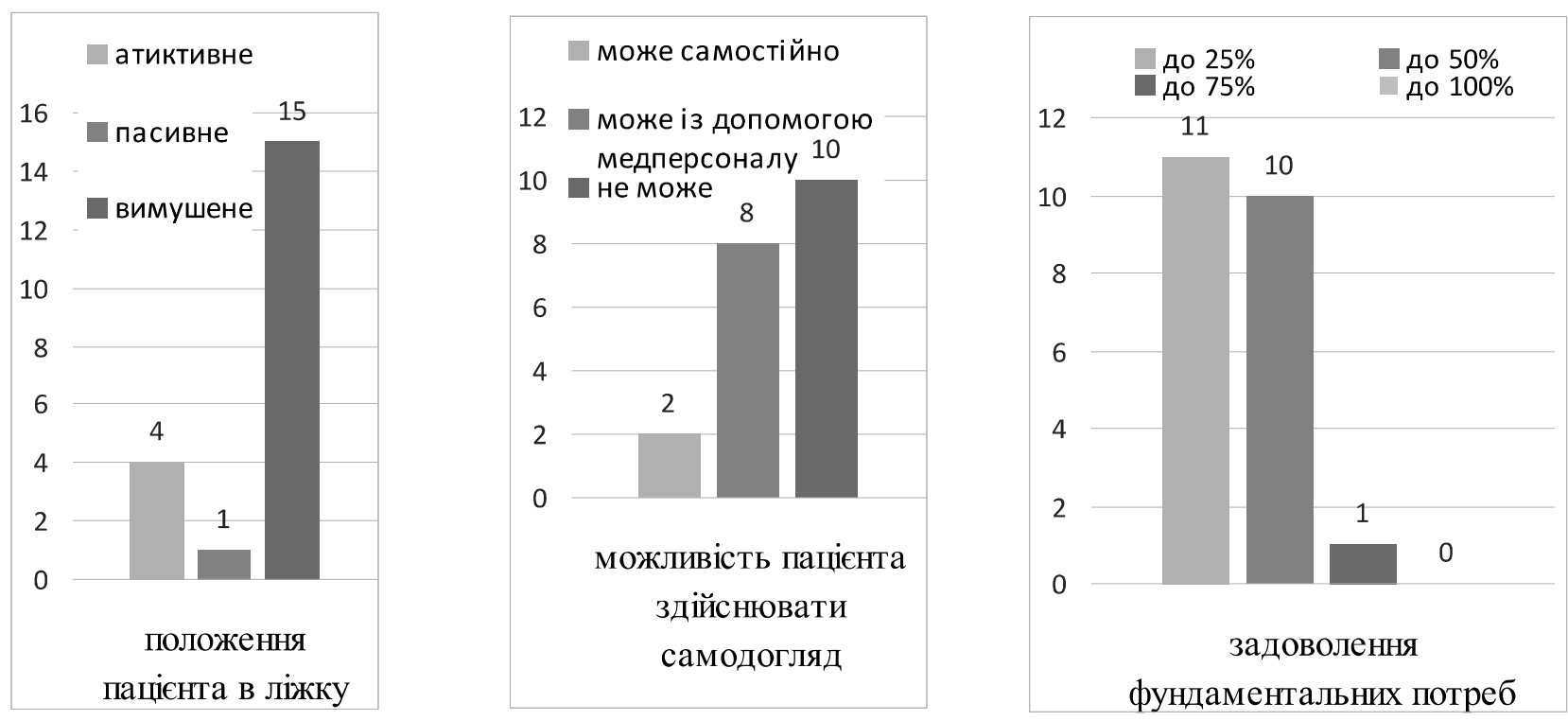

Puc. 2. Дані медсестринського обстеження пацієнтів Волинської обласної лікарні «Хоспіс».

новому побачити ситуацію, переоцінити цінності, знайти сенс власного існування, дійсно зрозуміти себе. Це шанс вирватися зі звичних стандартів поведінки, стати собою. Самотність, яку можна використовувати саме таким чином, Карл Мустакас назвав істинною самотністю. Вона проявляється в момент критичної життєвої ситуації (народження, смерть, тяжкі переживання в житті). Самотність іманентно притаманна людському існуванню, тільки вона не завжди усвідомлюється. У ті рідкісні моменти, коли це відбувається, потрібно вміти їі продуктивно використати. Цьому можна навчитися, подолавши свій страх перед цим станом [5]. Саме в інкурабельного пацієнта в момент критичної життєвої ситуації можливий розвиток істинної самотності, яка $\epsilon$ логічним наслідком і не пов'язана із дефіцитом спілкування чи уваги оточуючих.

\section{ЛІТЕРАТУРА}

1. Помазова О. В. Самотність як психологічний феномен / О. В. Помазова // Наукові записки Національного університету «Острозька академія». Психологія і педагогіка. 2013. - Вип. 23. - С. 206-214.

2. Корчагина С. Г. Генезис, виды и проявления одиночества / С. Г. Корчагина. - М. : Московский психологосоциальный институт, 2005. - 196 с.

3. Пепло Л. Одиночество и самооценка / Л. Пепло М. Мицелии, Б. Мораш // Лабиринты одиночества : пер. с
Висновки. Самотність - одна з проблем у забезпеченні психологічного благополуччя пацієнта хоспісу. Це гостре внутрішнє, суб'єктивне переживання. у більшості пацієнтів Волинської обласної лікарні «Хоспіс» діагностовано середній (60 \%) та низький (35\%) рівень суб'єктивного відчуття самотності. Вважаємо, що ці показники зумовлені тяжким фізичним станом пацієнта та пов'язаними із цим переживаннями. Аналіз різноманітних підходів до феномена самотності дозволяє аргументувати, що самотність як психологічне явище потребує уваги медичних сестер паліативних відділень, хоспісів, оскільки вони проводять з пацієнтами найбільше часу. Медсестра - ключова особа в оточенні пацієнта, яка забезпечує належну медичну допомогу, кваліфікований догляд та психологічну підтримку.

англ. ; сост., общ. ред. и предисл. Н. Е. Покровского. - М. : Прогресс, 1989. - С. 169-191.

4. Перепелиця А. Вплив здібностей на формування професійно важливих якостей майбутньої медичної сестри / А. Перепелиця // Педагогіка і психологія професійної освіти. - 2013. - № 4. - С. 203-212.

5. Ястремська С. О. Роль медичних сестеру паліативній (хоспісній) допомозі / С. О. Ястремська, О. С. Усинська // Медсестринство. - 2011. - № 3. - С. 4-8. 